\title{
ИНТЕРДИСЦИПЛИНАРНОСТА КАКО СТОЖЕР НА НАУЧНОИСТРАЖУВАЧКАТА МИСЛА И ПРАКТИКА
} (Зборник на трудови од меѓународната конференција: Студии по англистика - Интердисциплинарност во истражувањето и практиката (ЕСИДРП), М. Беќар, К. Малеска и Н. СтојановскаИлиевска (уредници), Скопје, 2016)

\section{INTERDISCIPLINARITY AS A PIVOT OF RESEARCH AND PRACTICE}

(Proceedings of the ESIDRP International Conference: English Studies at the Interface of Disciplines: Research and Practice (ESIDRP), M.

Bekar, K. Maleska and N. Stojanovska-Ilievska (editors), Skopje, 2016)

Милан Дамјаноски

Универзитет „Св. Кирил и Методиј“, Скопје

mdamjanoski@gmail.com

Milan Damjanoski

Ss. Cyril and Methodius University, Skopje mdamjanoski@gmail.com

Една од одликите која треба да ја краси секоја институција, а особено научнообразовните институции, е традицијата. Таа не е лесно да се одржи во овие времиња на транзиција и тешки општествени и економски околности кои не секогаш се погодни за науката и академската работа. Но, некогаш најтешко е да се направи првиот чекор со кој ќе се започне една нова традиција. Катедрата за англиски јазик и книжевност при Филолошкиот факултет „Блаже Конески“ во Скопје го направи токму тој прв чекор со 
организирањето на конференција ESIDRP (English Studies at the Interface of Disciplines: Research and Practice, Студии по англистика Интердисциплинарност во истражувањата и практиката), која е замислена да биде традиционална конференција што ќе се одржува на секои три години. Идејата е со оваа конференција да се соберат на едно место различните генерации кои произлегле низ годините од Катедрата, како и да се овозможи простор каде научниците, академскиот кадар и практичарите од областа на англиските студии од земјата, регионот и пошироко би ги презентирале своите истражувања, но и би се дискутирало за најновите трендови и тенденции во англистиката. Воедно, областите кои се опфатени во рамките на програмата на конференцијата имаат за цел да ја одразат комплексноста и мултидисциплинарноста на англистиката како научна гранка.

Еден од најважните исходи од организирањето на конференцијата секогаш е зборникот на трудови кои произлегуваат од неа, а кој во една трајна форма треба да ги отелотвори и зачува принципите и идеите за кои се залагаат организаторите и учесниците на ESIDRP конференцијата. Зборникот на трудови содржи 36 текстови поделени во четири тематски делови: Пленарни говори; Книжевност, култура и книжевен превод; Лингвистика (применета лингвистика, англиски како странски јазик, превод и толкување) и Студентски трудови. Уредници на Зборникот се: Мира Беќар, Калина Малевска и Наташа Стојановска-Илиевска, а тие во својата работа беа поддржани од Меѓународниот одбор на рецензенти составен од еминентни професори и стручњаци од сите опфатени научни дисциплини. Рецензентите дадоа свој непроценлив придонес во трудовите да се запазат сите научни, истражувачки и академски стандарди. Членови на Меѓународниот одбор се: Марк Вајат, Клаудија Јоана Дорохолчи, Слободанка Димова, Елени Бужаровска, Зоран Анчевски, Драги Михајловски, Бенџамин Китинг, Џонатан Мекриди, Марија Багашева-Колева и Лилјана Марковиќ. Зборникот е посветен на прерано починатиот колега и еден од најдобрите преведувачи од англиски јазик Огнен Чемерски, кој беше незаменлив член на Катедрата за англиски јазик и книжевност и на Организацискиот одбор на конференцијата, а чие заминување претставува ненадоместлива загуба за македонската наука, превод, англистика и за Филолошкиот факултет.

Интердисциплинарноста повторно е sвезда водилка, како и главна одлика на Зборникот на трудови од ESIDRP конференцијата, што веднаш може да се согледа од пленарниот говор на Мајкл Арон Рокланд, со кој не само што се отвори конференцијата, туку и Зборникот. Рокланд на еден својствен отворен и бескомпромисен начин го поставува прашањето зошто академската јавност во блиското минато, а и сега, има страв да се занимава и да ѝ даде легитимитет на популарната култура. Тој го дава примерот на приемот на популарниот роман бестселер Долината на куклите, кој и покрај милионскиот тираж е игнориран и категоризиран како „треш“ култура, иако неговата рецепција може да послужи како добра студија на случај за подобро разбирање на американското општество и менталитет. Понатаму, Рокланд укажува на еден 
важен и универзален факт, дека денешната популарна култура во иднината ќе биде дел од елитната култура, што го илустрира преку примерите на романот, џезот, рокот, филмот, па дури и телевизиските серии. Заклучокот е дека науката не смее да се затвори во своите цврсти граници и елитизам, ако сака да ја исполни својата задача да го осознае светот, човештвото и најновите трендови во општеството.

Трудовите во поглавјето „Книжевноста, културата и книжевниот превод“ приоѓаат кон својата проблематика од повеќе различни правци и перспективи, преку визурата на различни научни дисциплини и теории. При тоа, заради полесно категоризирање, може да ги поделиме во неколку тематски целости. Во првите два труда, авторите сакаат да дадат критика и ново согледување на човечките односи и начинот на кој општеството ги дефинира, категоризира и нормира. Елизабета Баковска ги користи придобивките на современата феминистичка теорија и нејзините суштински концепти за повторно да ги разгледа и деконструира идеите за мајчинството и сестринството, како општествено нормирани односи на жените. Баковска како пример ги зема расказите на Дебора Кеј Дејвис собрани во збирката Грејс, Тамар и Ласло прекрасниот (2009) за да ја демистифицира стереотипната патријархална идеја за несебичната и посветената мајка, при што го прикажува искуството на мајчинството и раѓањето како комплексно, но често и шокантно и трауматично, како за мајката, така и за ќерката. Наместо овој идеал, Дејвис го сопоставува сестринскиот однос како најмоќно човечко искуство за жените кое може да служи како поттик и пример за феминистичката теорија како да се реконструира и реконципира женското искуство воопшто. Тијана Матовиќ, од друга страна, се повикува на новата теорија на траумата како свежа перспектива преку која можеме подобро да ја разбереме улогата на загубата во градењето на идентитетот и човечкото сеќавање. Нејзината анализа на романот на Казуо Ишигуро, „Никогаш не ме заборавај (2005), дистописки роман кој за тема го има клонирањето и прашањето на визијата за новото човештво, сепак се концентрира на етичката димензија на загубата и на тоа колку е таа важна за нашето чувство на себство во хаотичноста на светот околу нас. Матовиќ многу вешто се користи со концептите на психологијата и теоријата на траума за да ги осветли начините на кои се гради романескната, но и интимната нарација гледана преку сеќавањата и потиснувањата на траумите во човечкото искуство.

Втората голема тема на трудовите во ова поглавје се фокусира на односот со традицијата и преиспитувањето на нејзината историја и влијание од аспект на современите теории и практики. Лидија Капушевска-Дракулевска се навраќа на класикот на готската фикција, романот Франкенштајн на Мери Шели, при што преку историјата на неговото создавање, но и рецепција низ годините, го покажува неговото несомнено влијание врз развивањето на прашањето на Другиот, едно од темелните концепти на современата филозофија и теорија на книжевност. Капушевска-Дракулевска го осветлува овој комплекс од етичко-морална, антрополошка, психоаналитичка, како и 
родова перспектива со што преку овој интердисциплинарен пристап ги осветли причините зошто овој роман и митот за научникот и неговата творба e cè уште актуелен во културата, книжевноста, филмот, но и во промислувањето на новите предизвици кои ги носи развојот на науката и технологијата. Соња Стојменска-Елзесер во својот труд говори за контроверзите поврзани со идеите на еден од најпознатите книжевни теоретичари на 20 век, Харолд Блум искажани во неговото дело, Западниот канон (1994). Стојменска-Елзесер прикажува една од најзначајните полемики помеѓу традиционалната книжевна теорија и современите постструктуралистички теории, односно што претставува и како се создава книжевниот канон. Ова прашање е сѐ уште поле на конфликт и жолчни расправии како дел од т.н. „културни војни“, но историјата на дебатите поврзани со Блум и неговите идеи е полезно четиво за релативноста и променливоста на идејата за канонот како камен- темелник на светската и националната книжевност. Јилдирај Челик, пак, се осврнува на уште еден каконизиран концепт, а тоа идејата за ,јужњачката дама““, популаризирана во драмите инспирирани од Американскиот Југ од времето на Граѓанската војна во САД. Преку анализата на женските ликови во драмите на Тенеси Вилијамс, Челик воедно ни дава историска, социолошка и културна анализа на подемот и падот на овој концепт, преку кој може да се согледаат и економските, општествените и политичките промени во американското општество.

Искра Тасевска-Хаџи Бошкова ни дава приказ за историјата на жанровите и го истакнува методолошкиот потенцијал на критиката на жанрот за подобро сфаќање на развојот и присутноста на наративноста во историјата на книжевноста. За да ја илустрира флексибилноста и трансформативноста на жанровите, Тасевска-Хаџи Бошкова се осврнува на современиот македонски епистоларен роман Исток - Запад на Јадранка Владова и Небојша Кнежевиќ за да покаже дека нарацијата е најподатлива алатка за толкување и креирање на личната и историската свест. Бојан Меџедовиќ се осврнува на жанрот на фантазијата и неговиот негативен третман од традиционалната критика како „грдо пајче“ на книжевноста. Меѓуутоа, промените кои настанаа во модерното општество, развојот на новите медиуми и дигиталната револуција доведуваат до негово воскреснување и трансформација во најпопуларниот жанр, своевиден ,лебед“ на книжевноста на новото време, што може да се види од популарноста на делата на Толкин, Мартин и Роулинг.

Интердисциплинарноста е инхерентна на самата книжевност како творештво, а ништо тоа не го отелотворува појасно од интертекстуалноста како суштински квалитет кој овозможува комуникација меѓу периодите, авторите и делата, но и нивно повторно оживување, преиспитување и пресоздавање. Следната група автори ги користи придобивките на интертекстуалноста и соработката меѓу различните книжевни жанрови како инспирација за ново и свежо обмислување на одредени класични дела. Калина Малеска во нејзината анализа за негативната критика на крајот на Мартин Идн од Џек Лондон, наоѓа нови и убедливи аргументи во нејзината 
одбрана на психолошката втемеленост на постапките на главниот лик, во концептот на Мурти-Бинг пилулите за заборав во славното дело Заборавениот ум на Чеслав Милош. Малевска со тоа ни дава еден впечатлив пример како идеите од дела и дисциплини кои се чинат неповрзани со нашиот предмет на интерс можат да дадат нов поттик и решенија за успешна анализа. Катерина Клинкова, пак, се повикува на идејата за временски слики на еден од најзначајните постструктуралиситички теоретичари Жил Делез, за да понуди нова анализа на поезијата на Т. С. Елиот, со што овозможува неговата поезија да се види од една современа песпектива. Конечно, како заокружување на оваа тенденција на преиспитување на традицијата и на класичните дела, Трајанка Кортова ни дава една постколонијална критика на ликот и приказната на Робинзон Крусо, но дадена посредно и интертекстуално преку романот Фо на нобеловецот Џ.М. Куци. Куци врши една метафикциска интервенција на својот претходник, со што го воведува женскиот лик Сузан, но во исто време му дава една нова и посуштествена наративна улога на Петко. Кортова ни укажува дека тоа го прави со цел да ги воведе новите дискурси на феминизмот и постколонијализмот, но и да изврши критика на институциите и дискурсот на апартхејдот во неговата родна Јужна Африка. На тој начин, интертекстуалноста служи како моќна алатка за преиспитување на доминантните идеологии, дискурси и наративи.

Книжевноста во својата суштина претставува интермедијална уметност на што укажуваат трудовите на неколку автори. Иванка Трајановска преку серијата на романи Аиилак на Дороти Ричардсон ни дава преглед на типологијата на С. П. Шер за трите типови на интермедијалност: книжевност во музиката, музиката и книжевноста и музиката во книжевноста. Потоа, во останатиот дел од трудот Трајановска ги илустрира важноста и продуктивноста на содејството на музиката и зборот во креирањето на уникатната поетика на Ричардсон. Џејмс Џојс и неговите дела претставуват ултимативен идеал и пример за книжевноста како интермедијално и интержанровско творештво, со што го привлекуваат вниманието на двајца наши автори. Џонатан Мекриди ни дава интересен приказ на улогата на масонските симболи и иконографија во градењето на романескната структура и семантичко богатство во Бдеењето на Финеган, додека Марија Гиревска укажува на прашањето за преводливоста на Џојс, авторот кој претставува Монт Еверест за секој преведувач, преку анализа на преводот на поглавјето „Итака“ од неговото ремек дело Улис на повеќе словенски јазици. Преводот на уште еден современ роман Пеколен портокал од Ентони Бурџис е темата на трудот на Зорица Петковска, која особено се осврнува на справувањето со преводот на Надсат жаргонот кој е еден од главните наративни стратегии на Бурџис. Бидејќи тој е базиран на рускиот јазик, се поставува прашање колку ќе се изгуби од очуденоста како важен семантички пристап во случај на превод на близок словенски јазик, како што е македонскиот. Горан Ивковиќ ги испитува од структурен аспект меѓусебните односи на ликовите во драмата Чехов му вели збогум на Толстој на современиот хрватски драматург Миро 
Гавран, додека Емилија Крагуевска го разгледува третманот на имињата на ликовите на двојниците во Шекспировите драми. Со последните два труда се потврдува плодотворната примена на другите научни дисциплини и во анализата на драмата.

Втората голема тематска целина во Зборникот е посветена на трудовите од областа на лингвистиката, при што се опфатени теми од применетата лингвистика, наставата по англиски како странски јазик, превод и толкување. Знаејќи дека лингвистиката беше наука која во 20 век изврши големо и трансформативно влијание врз другите хуманистички дисциплини, не изненадува фактот дека преку науката за јазикот се согледува, анализира и истражува еден широк спектар на трендови во општеството кои наоѓаат своја рефлексија и израз во јазичните процеси. При тоа, се става акцент на примената на најновите теориски модели и истражувачки методи како што се когнитивната лингвистика, корпусната лингвистика, анализата на дискурсот, да споменеме само некои. Како и во сите трудови од овој Зборник, интердисциплинарноста е суштинска карактеристика и водечки пристап при што лингвистичките концепти и методи на анализа се применуваат на проблематики кои произлегуваат од областите на книжевноста, новинарството, наставата по англиски јазик, а не се забораваат и современите медиуми за комуникација како што е интернетот.

Најдобар пример за сеопфатна и темелна примена на сите овие елементи се наоѓа во трудот на Елени Бужаровска и Лилјана Митковска со кој се отвара овој дел од Зборникот, а кој претставува поглед од аспект на когнитивната лингвистика на моделите на реченични дополненија на глаголот се надева. Главна цел на овој труд е да се покаже дека голема улога во синтаксичката варијабилност на дополненијата на овој глагол имаат семантичките, прагматичките и стилистичките фактори. Теориско-методолошкиот инструментариум се базира на концептите земени од когнитивната лингвистика, когнитивно/функционалниот пристап кон комплементацијата, како и методите на корпусната лингвистика со што како основа на истражувањето се земени примери од Корпусот на современ американски англиски јазик ${ }^{l}$. Во таа насока, интересен е и трудот на Ненад Миладиновиќ во кој се дава историски преглед на еволуцијата на генитивниот маркер 's во англискиот јазик. Тој врши едно морфосинтаксичко истражување при што, преку примери, ни ги покажува промените во морфолошкиот статус со текот на времето од суфикс за контекстуална инфлекција, преку клитика до во поново време, суфикс за инхерентна инфлекција. Истражувањето на Румјана Благоева ја илустрира полезноста на големите електронски корпуси на говорен англиски јазик, како што е LINDSEI, кој опфаќа говорители од 11 различни држави. Авторката врз основа на овој корпус спроведува

\footnotetext{
${ }^{1}$ Corpus of Contemporary American English - COCA https://www.english-corpora.org/coca/
} 
квантитативна анализа базирана на корпусната лингвистика за да утврди кои дискурсни маркери најчесто ги користат бугарските студенти по англиски јазик со цел да се изнајдат најсоодветни методи во наставата за да се избегне нивната претерана или несоодветна употреба.

Анализата на дискурсот како продуктивен аналитички модел е прикажан во трудот на Десислава Стојанова посветен на известувањето во британските и бугарските медиуми за два одделни терористички напади во Франција и во Русија. Критичката анализа на медиумскиот дискурс, како и на лингвистичките форми за изразување на чувствата на жалост и солидарност на социјалните мрежи, покажа дека големо влијание врз нив имаат политичките преференции во дадените општества, како и потребата на медиумите за сензационализам и привлекување на читателите. Влијанието врз формите и начините на комуникација од страна на современите медиуми како што е интернетот, како и изразувањето на личниот и општествениот идентитет е фокусот на трудот на Мира Беќар. Со примена на анализа на дискурсот и разговорите на испитаниците во нивната електронска комуникација, Беќар прикажува како лингвистичката и друштвената природа на онлајн комуникацијата влијае врз стратегиите кои ги користат говорителите за да постигнат усогласување во комуникацијата и во одржувањето на личните односи. Конечно, Јања Чулиг фрла светлина на тоа како лингвистичките методи може да се искористат во книжевните истражувања, преку нејзината анализа на концептуалните метафори на светлината во Кон светилникот на Вирџинија Вулф. Преку методите на когнитивната лингвистика, поетика и теоријата на концептуалните метафори, таа укажува дека со нивна помош книжевните теоретичари и критичари можат да откријат нови аспекти во стилот и творештвото на писателите и нивната творечка поетика.

Еден од најважните аспекти од практичната примена на лингвистиката е наставата по англиски јазик во образовниот процес, па затоа следниот блок на трудови се фокусира на истражување на процесот на учење на англискиот како странски јазик и утврдување на начини и стратегии за постигнување на подобри резултати во наставата. Билјана Наумоска-Саракинска го разгледува прашањето на деривацијата како зборообразувачки процес, со акцент на деривацијата на именски придавки во учењето на англиски како странски јазик. Ивана Дуцкиновска се осврнува на прашањето на варијациите во изговорот кај изучувачите на англискиот јазик, особено на предлозите и сврзниците како важни структурни елементи на јазикот. Вероника Карева, пак, се осврнува на многу актуелното прашање за видот на вештините кои студентите ги стекнуваат во рамките на високото образование и дали се тие доволни за да се подготват да излезат на пазарот на трудот. Конечно, Марта Новацка и Беата Веб говорат за потребата од запознавање со различните и некогаш подалечните варијанти на англискиот јазик, како што e австралискиот, преку истражувањето колку се запознаени полските студенти со австралиската терминологија и култура. 
Последниот блок на трудови се занимава со лингвистичките аспекти на преводот од англиски јазик во повеќе области. Нина Манојловиќ ги разгледува предизвиците во преведувањето на правната проблематика и терминологија, прашање кое е доста релевантно, особено заради потребата за транспонирање на законодавството на ЕУ. Арта Бектеши, врз примерот на албанскиот превод на Белиот очњак на Џ. Лондон, ги разгледува можните преводни варијанти на сврзникот за временски зависносложени реченици when. Силвана Нешковска и Соња Китановска-Кимовска, исто така, се занимаваат со проблематиката на книжевниот превод и предизвикот да се преведе иронијата. Како предмет на анализа го земаат македонскиот превод на познатата драма на Оскар Вајлд која Драги Михајловски ја адаптира како Важно е да си Богумил. Преку различните стратегиите за пренесување на вербалните сигнали на иронијата, авторките укажуваат на предизвиците со кои се соочуваат преведувачите од лингвистички, креативен и културен аспект. Се разбира, тие обиди не секогаш се успешни и можат да доведат до сосема несоодветни преводни решенија, што е темата на текстот на Катерина Ѓурчевска-Атанасовска. Анализирајќи го македонскиот превод на збирката раскази на Рејмонд Карвер, таа ја посочува важноста на идиоматските изрази во формирањето на стилот на еден автор, а грешките при преводот може да доведат до минимизирање на стилската димензија на текстот, како и губење на значењето или несоответно значење во дадениот контекст. Сето ова укажува на важноста на одличното познавање на јазикот и културата од која се преведува, на што се однесува и последниот труд со кој се затвора ова поглавје на Зборникот. Во своето истражување од областа на конференциското толкување, Емилија Саржовска-Георгиевска ја потенцира улогата на толкувачот како посредник меѓу култури, базирајќи се на теоријата на смислата во толкувањето на Селешковиќ, но и на искуствата на анкетираните професионални толкувачи кои наведуваат соодветни стратегии при преведувањето и толкување на културно специфични поими и концепти.

Како што напоменавме во уводот, една од примарните цели на ESIDRP конференцијата е вклучувањето и промовирањето на новите генерации на студенти од Катедрата за англиски јазик и книжевност. Тие ја претставуваат иднината на англистиката во земјата, како и подмладок од кој ќе се регрутираат новите научници, истражувачи, професори, наставници и практичари кои ќе ја продолжат и зацврстат традицијата на англистиката во нашата држава. Затоа сме особено горди и задоволни што како дел од нашиот Зборник имаме трудови од 4 наши студентки. Како и останатите текстови, и нивните трудови, со добра теориска предлошка, ја одразуваат идејата за интердисциплинарност, со изразит фокус на апликативноста на нивните наоди во практиката на наставата по англиски јазик. Ајнур Касо се повикува на моделот на стратешка саморегулација на Ребека Оксфорд при анализата на интегрирањето на стратешките упатства во два учебника за англиски јазик кои се користат во македонскиот образовен систем, наменети за млади и возрасни ученици. При тоа, наодите од трудот се наменети за подигање на 
свесноста на наставниците за важноста на стратегиите за учење. Вера Тошевска се концентрира на анализа на начинот на говорење на наставниците во контекстот на учење на англискиот како странски јазик. Главен фокус се става на односот на користење на изворниот и целниот јазик и важноста на постигнување на добра рамнотежа меѓу двата за подобро совладување на англискиот јазик од страна на учениците во училницата. Катерина Боглева говори за еден многу важен проблем во нашето образование, а тоа е интегрирањето на учениците со посебни потреби во наставата. Преку набљудување и лични разговори, Боглева покажува дека учениците со благи попречености можат да постигнат напредок ако наставникот се потруди да го прилагоди наставниот план во согласност со нивните потреби. Конечно, последниот труд е од областа на книжевноста, во кој Ана Калајџиева дава приказ на многу актуелниот современ жанр на сајберпанкот кој ја одразува естетиката на постмодернизмот, но во исто време е антитеза на утописките прикази на иднината. При тоа, Калајџиева ги претставува филозофските и егзистенцијалистичките прашања и конфликти кои се јавуваат во рамките на овој жанр, особено прашањето на разликувањето помеѓу реалното и фикциското, едно од горливите прашања на нашето дигитално време.

Како заклучок на овој приказ на Зборникот на трудови од ESIDRP конференцијата, можеме само да кажеме дека тој претставува прв чекор во, се надеваме, воспоставување на една долга и продуктивна традиција. Трудовите на авторите застапени во него, како и презентациите на сите учесници на конференцијата ни даваат за право како членови на Организацискиот одбор и на Катедрата за англиски јазик и книжевност, да сметаме дека сме ја исполниле целта да покажеме дека англистиката е една интердисциплинарна наука која комуницира со современите текови и трендови. Учеството на нашите поранешни и сегашни студенти, пак ни дава надеж, дека англистиката во државата е поставена на здрави основи и дека конференцијата ќе успее и во иднина во својата мисија да ги обедини на едно место сите генерации. 